\title{
Association of interleukin 2, interleukin 12, and interferon- $\gamma$ with intervertebral disc degeneration in Iranian population
}

Sara Hanaei ${ }^{1,2,3}$, Sina Abdollahzade ${ }^{4}$, Maryam Sadr ${ }^{1}$, Mohammad Hossein Mirbolouk ${ }^{5}$, Ehsan Fattahi ${ }^{5}$, Alireza Khoshnevisan ${ }^{5}$ and Nima Rezaei ${ }^{2,3,6^{*}}$ (D)

\begin{abstract}
Background: Intervertebral disc degeneration (IVDD) is an age-related degenerative disease, presenting with low back pain or radicular pain. The inflammatory changes would occur in discs in the process of IVDD. Therefore, the inflammatory and anti-inflammatory cytokines, as well as their respective genes, have been proposed to play roles in pathophysiology of disease. This study has been conducted to elucidate the role of IL-2, IL-12, and IFN- $\gamma$ single nucleotide polymorphisms (SNP) in this disease.

Method: Seventy-six patients who were diagnosed with IVDD and 140 healthy controls who complied with eligibility criteria were included. A total volume of $5 \mathrm{cc}$ peripheral blood was obtained from each participant to investigate the IL-2 + 166G/T, IL-2 -330G/T, IL-12 - 1188A/C, and IFN- $\gamma+847 \mathrm{~A} / \mathrm{T}$ SNPs through PCR-SSP method.

Results: The ' $T G$ ' and ' $T$ ' genotypes of IL-2 - 330G/T polymorphism were significantly more common among patients and healthy controls respectively. The 'GT' and 'TT' haplotypes of IL-2 (comprised of $-330 \mathrm{G} / T$, and $+166 \mathrm{G} / T$ SNPs) were also more common among patients and controls respectively.

Conclusion: This study indicated the significant role of IL-2 genotypes and haplotypes in IVDD. These SNPs were differently distributed in patients and controls. Therefore, alteration in the structure of IL-2 gene could play an important role in pathophysiology of IVDD.
\end{abstract}

Keywords: Intervertebral disc degeneration, Single nucleotide polymorphism, Interleukin 2, Interleukin 12, Interferon Y, Immunogenetics, Cytokine

\section{Background}

Intervertebral disc degeneration (IVDD) is one of the common causes of discogenic low back pain, which is considered a frequent health problem in adults. This disease affects the patients' quality of life and also has the negative impact on the length of their productive life [1].

\footnotetext{
* Correspondence: rezaei_nima@tums.ac.ir

${ }^{2}$ Research Center for Immunodeficiencies, Children's Medical Center, Tehran University of Medical Sciences, Dr Qarib St, Keshavarz Blvd, Tehran 14194, Iran

${ }^{3}$ Network of Immunity in Infection, Malignancy and Autoimmunity (NIIMA), Universal Scientific Education and Research Network (USERN), Tehran, Iran Full list of author information is available at the end of the article
}

Although the mechanical load on the discs and aging are considered as the most important causes of IVDD, genetic and immunologic predispositions have been widely discussed especially in the past 2 decades [1]. Accordingly, the individuals with specific genetic predispositions, such as single nucleotide polymorphisms (SNP) of immunologic modulators and cytokines, would be more prone to develop IVDD. Also they might be affected with severe grades of IVDD or develop disease in younger ages [1].

Generally, innate immunity and inflammation play important roles in IVDD occurrence. The inflammation

(c) The Author(s). 2020 Open Access This article is licensed under a Creative Commons Attribution 4.0 International License, which permits use, sharing, adaptation, distribution and reproduction in any medium or format, as long as you give appropriate credit to the original author(s) and the source, provide a link to the Creative Commons licence, and indicate if changes were made. The images or other third party material in this article are included in the article's Creative Commons licence, unless indicated otherwise in a credit line to the material. If material is not included in the article's Creative Commons licence and your intended use is not permitted by statutory regulation or exceeds the permitted use, you will need to obtain permission directly from the copyright holder. To view a copy of this licence, visit http://creativecommons.org/licenses/by/4.0/ The Creative Commons Public Domain Dedication waiver (http://creativecommons.org/publicdomain/zero/1.0/) applies to the data made available in this article, unless otherwise stated in a credit line to the data. 
would cause destructive damages to the discs through its mediators including pro-inflammatory cytokines and also other cytokines (interleukins, interferons), enzymes and growth factors. Interleukin 2 (IL-2), located on $4 \mathrm{q} 27$, is mainly produced by mature T-cells and participates in development of T-cells and B-cells, as it can function as a growth factor for them [2].

The gamma interferon (IFN- $\gamma$ ), which is located at $12 \mathrm{q} 15$, is a cytokine with important roles in immunity and immune related diseases. Its expression would remarkably increase during the inflammatory reactions [2]. In the process of disc degeneration, and disc herniation, the IFN- $\gamma$ is one of the inflammatory components which is upregulated in disc nucleous pulposus (NP), and affects tissue-specific macrophages in NP [3]. When produced by $\mathrm{T}$ helper 1 lymphocytes in the discs, IFN- $\gamma$ participates in macrophage activation, which could be considered as an immune response to herniation of NP [4]. Moreover, IFN- $\gamma$ plays a role in pathogenesis of neuropathic pain as well [5]. As the IFN- $\gamma$ is upregulated in neuroinflammation, as well as affecting the nociceptive neurons, any structural change in its gene, which results in higher expression, could possibly play a role in pathogenesis of disease. Therefore, some specific SNPs of this gene have been found to affect its expression levels [3].

Interleukin 12 (IL-12) is a cytokine with main role of connecting innate and acquired immunity [2]. Together with other factors and immune-related molecules, this cytokine plays a role in IVDD as well. Similar to IFN- $\gamma$, the IL-12 level was found higher in disc fragments caused by disc herniation [4].

As the important role of genetic and immunologic predisposition to IVDD, we have investigated the association of IVDD with different cytokines so far, including the proinflammatory cytokines, interleukin 4,10 , and TGF- $\beta$ [6-8]. Although the expression levels of some other cytokines including IL- 2 and IFN- $\gamma$ have been of interest in some other studies, the association of their SNPs have not been investigated yet. Therefore, the aim of current study was to evaluate the association of IL-2, IL-12, and IFN- $\gamma$ SNPs in Iranian patients with IVDD, as well as their association with post-operative pain reduction in this population.

\section{Method}

\section{Patient selection}

Seventy-six adult patients of both sexes with history of chronic low back pain who were diagnosed with intervertebral disc degeneration, and indicated for surgical intervention have been included in this study. The diagnosis was confirmed with both clinical manifestations and lumbosacral MRI. Patients with other etiologies of low back pain including trauma, malignancies, scoliosis, infections, spondylolysthesis, spondylolysis, and inflammatory disease affecting spine were detected ineligible to participate in this study. The control group $(N=140)$ has been selected among adult subjects of both sexes and same ethnicity without history of chronic low back pain or intervertebral disc degeneration. Participation in the study has been voluntary for all study subjects. Written informed consent to participate was obtained from all study participants before recruitment and sampling. The study has been approved by Ethics Committee of Tehran University of Medical Sciences.

\section{Assessment of visual analogue scale (VAS) and Oswestry disability index (ODI)}

The VAS and ODI were assessed in patients, at the time points of pre-operative, 2 months post-operative and 6 months post-operative. In order to assess the VAS, the patients were requested to score their pain on scale of 1-10. Score 1 indicated the lowest degree of pain and score 10 indicated the highest degree. The ODI was assessed using a questionnaire as described before [9]. Then the difference of measurements between two time points were analyzed in order to investigate if a specific gene variant was associated with significant change in VAS or ODI.

\section{Blood sampling, DNA extraction, and polymerase chain reactions (PCR)}

A total volume of $5 \mathrm{cc}$ peripheral blood was obtained from all patients and controls in falcon tubes containing EDTA, and stored in $-20^{\circ} \mathrm{C}$ prior to DNA extraction. Previously described by Loparev V. et al. [10], genomic DNA was extracted with Phenol-Chloroform method. In order to detect the quality of extracted DNA, the optical density (OD) and 260/280 ratio were measured with NanoDrop. Four SNPs including IL-2 + 166G/T, IL-2 $-330 \mathrm{G} / \mathrm{T}$, IL-12 - 1188A/C, and IFN- $\gamma+847 \mathrm{~A} / \mathrm{T}$ have been genotyped through Sequence Specific Prime PCR (PCR-SSP) method using Cytokine CTS-PCR-SSP TRAY KIT (University Clinic Heidelberg, Heidelberg, Germany) protocol. In brief, the 96-well reaction plate of cytokine kit contained a total volume of $10 \mu \mathrm{l} /$ well solution, which was comprised of $1.44 \mu \mathrm{l}$ Master Mix,

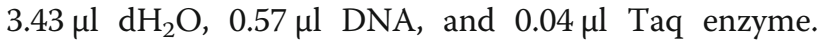
The PCR reactions have been performed accordingly to the kit protocol.

\section{Statistical analysis}

Distributions of qualitative variables, such as alleles and genotypes, were reported as frequencies. The association between two qualitative variables was assessed through calculating odds ratio (OR) and $\mathrm{Chi}^{2}$ test. The respective $P$-value was determined as indication of significance and 
$P<0.05$ was considered statistically significant in all tests.

\section{Results}

Association of cytokine (IL-2, II-12, and IFN- $\gamma$ ) allele and genotype distributions with intervertebral disc degeneration

Genotype distribution of IL-2 promoter polymorphism $(-330 \mathrm{G} / \mathrm{T})$ was significantly associated with IVDD, as 'TG' genotype was 2.05 times more common among patients $(P=0.05)$, while the 'TT' genotype was more frequent among healthy subjects $(P=0.03)$. However, other investigated polymorphisms failed to show any significant association with IVDD in either allele or genotype distribution (Table 1).

\section{Association between cytokine haplotype distribution and intervertebral disc degeneration}

Considering two polymorphisms of IL-2 together (the $-330 \mathrm{G} / \mathrm{T}$ and + 166G/T SNPs), two haplotypes were differently distributed in patients and controls. While 'GT' haplotype was more frequent among patients, the 'TT' haplotype was more common among healthy subjects $(\mathrm{OR}=0.44, P=0.009)($ Table 2$)$.

\section{Association of II-2 and IFN- $\gamma$ polymorphisms with} Oswestry disability index and visual analogue scales The allele and genotypes of IL- 2 and IFN- $\gamma$ were considered for evaluating their association with post-operative pain reduction. The association between each allele or genotype and pain indices are shown in detail in Tables $3,4,5$ and 6 . Among them, only IL-2 $-1188 \mathrm{~A} / \mathrm{C}$ indicated significant association with 6-month postoperative ODI reduction.

\section{Discussion}

To our knowledge, the current study was one of the firsts to investigate the association of cytokine polymorphisms including IL-2 $(-330 \mathrm{~T} / \mathrm{G},+166 \mathrm{G} / \mathrm{T})$, IL-12 $(-1188 \mathrm{~A} / \mathrm{C})$ and IFN- $\gamma(=874 \mathrm{~A} / \mathrm{T})$ with intervertebral disc degeneration (IVDD) in Iranian patients. Among all the investigated SNPs, only the IL-2 -330 T/G was significantly associated with disease, and was twice more common in patients than controls. Besides, the haplotype of IL-2 $(-330,+166)$ was also significantly associated with IVDD, as the 'GT' haplotype was more frequent in IVDD patients. However, other investigated SNPs failed to show any association with IVDD in this population.

The role of immunity, as well as the cytokines of interest in this study, were investigated in a number of

Table 1 The frequencies of cytokine alleles and genotypes in IVDD patients and healthy controls

\begin{tabular}{|c|c|c|c|c|c|c|c|}
\hline Cytokine & Position & Alleles/ Genotypes & $\begin{array}{l}\text { IVDD } \\
\text { N (\%) }\end{array}$ & $\begin{array}{l}\text { Control }(\boldsymbol{N}=140) \\
\text { N }(\%)\end{array}$ & $\boldsymbol{P}$-Value & OR & $95 \% \mathrm{Cl}$ \\
\hline \multirow[t]{5}{*}{ IL-12 (N=71) } & \multirow[t]{5}{*}{-1188 (rs3212227) } & A & $103(72.5)$ & 204(72.9) & 1.00 & 0.98 & $0.63-1.55$ \\
\hline & & C & $39(27.5)$ & $76(27.1)$ & 1.00 & 1.02 & $0.65-1.58$ \\
\hline & & $\mathrm{AA}$ & $40(56.3)$ & $72(51.4)$ & 0.56 & 1.22 & $0.69-2.16$ \\
\hline & & CA & $23(32.4)$ & $60(42.9)$ & 0.18 & 0.64 & $0.35-1.16$ \\
\hline & & $C C$ & $8(11.3)$ & $8(5.7)$ & 0.17 & 2.09 & $0.75-5.84$ \\
\hline \multirow[t]{5}{*}{ IFN- $\gamma(N=74)$} & \multirow[t]{5}{*}{$+874($ rs2430561) } & A & $85(57.4)$ & $140(50.7)$ & 0.22 & 1.31 & 088-1.96 \\
\hline & & $\mathrm{T}$ & $63(42.6)$ & 136(49.3) & 0.22 & 0.88 & $0.51-1.31$ \\
\hline & & AA & $26(35.1)$ & $43(31.2)$ & 0.65 & 1.19 & $0.66-2.18$ \\
\hline & & AT & $33(44.6)$ & 54(39.1) & 0.47 & 1.25 & $0.71-2.19$ \\
\hline & & $\pi$ & $15(20.3)$ & $41(29.7)$ & 0.15 & 0.60 & $0.31-1.18$ \\
\hline \multirow[t]{5}{*}{ IL-2 (N=74) } & \multirow[t]{5}{*}{-330 (rs2069762) } & G & $68(46.0)$ & 110(39.6) & 0.21 & 1.31 & $0.88-1.97$ \\
\hline & & $\mathrm{T}$ & $80(54.0)$ & $168(60.4)$ & 0.21 & 0.76 & $0.50-1.13$ \\
\hline & & GG & $4(5.4)$ & $8(5.8)$ & 1.00 & 0.94 & $0.27-3.22$ \\
\hline & & TG & $60(81.1)$ & $94(67.6)$ & 0.05 & 2.05 & $1.03-4.06$ \\
\hline & & $\pi$ & $10(13.5)$ & $37(26.6)$ & 0.03 & 0.43 & $0.20-0.93$ \\
\hline \multirow[t]{5}{*}{ IL-2 (N=74) } & \multirow[t]{5}{*}{$+166($ rs2069763) } & G & $113(76.4)$ & 219(78.8) & 0.62 & 0.87 & $0.54-1.40$ \\
\hline & & $\mathrm{T}$ & 35 (23.6) & $59(21.2)$ & 0.62 & 1.15 & $0.71-1.85$ \\
\hline & & GG & $40(54.1)$ & $82(59)$ & 0.56 & 0.82 & $0.46-1.44$ \\
\hline & & GT & $33(44.6)$ & 55(39.6) & 0.56 & 1.23 & $0.69-2.17$ \\
\hline & & $\pi$ & $1(1.4)$ & $2(1.4)$ & 1.00 & 0.94 & $0.08-10.52$ \\
\hline
\end{tabular}


Table 2 The frequencies of IL-2 haplotypes in IVDD patients and healthy controls

\begin{tabular}{|c|c|c|c|c|c|c|}
\hline Cytokine & Haplotype* & $\begin{array}{l}\text { IVDD } \\
\text { N (\%) }\end{array}$ & $\begin{array}{l}\text { Control }(\boldsymbol{N}=140) \\
\text { N (\%) }\end{array}$ & $\boldsymbol{P}$-Value & OR & $95 \% \mathrm{Cl}$ \\
\hline \multirow[t]{4}{*}{ IL-2 } & GG & $48(32.2)$ & 107(38.8) & 0.20 & 0.75 & $0.49-1.14$ \\
\hline & TG & 65 (43.6) & 112(40.6) & 0.60 & 1.13 & $0.76-1.69$ \\
\hline & $\pi$ & $15(10.1)$ & $56(20.3)$ & 0.009 & 0.44 & $0.24-0.81$ \\
\hline & GT & $20(13.4)$ & $1(0.3)$ & - & - & - \\
\hline
\end{tabular}

*Reference: The IL2 haplotype was comprised of -330 T/G SNP (rs2069762), and + 166G/T SNP (rs2069763)

sturdies so far. Although the biomarker levels of these cytokines were investigated in a number of human studies or animal models, the role of SNPs were not widely investigated in the literature.

The IFN- $\gamma$ level would significantly change in low back pain. A recent investigation in 2019, indicated higher levels of IFN- $\gamma$ in acute low back pain compared with chronic low back pain or healthy subjects. Interestingly, the IFN- $\gamma$ level was not significantly different between chronic low back pain and asymptomatic individuals [11]. A considerable number of patients with IVDD who experience chronic low back pain may require surgical intervention, nevertheless, some of them may not response to this treatment either. The IFN $-\gamma$ expression level was associated with increased numeric rating scale. Accordingly, higher levels of IFN- $\gamma$ were detected in patients who did not respond to surgery. Spinal cord stimulation might be considered as an option for improving the pain and quality of life in these patients. However, in an investigation, IFN- $\gamma$ level was not significantly altered after the stimulation [5]. IFN- $\gamma$ levels were associated with acute low back pain, although its association with chronic low back pain was not significant [11]. While the IFN- $\gamma$ SNP did not show significant association with postoperative pain reduction in our study, the 'A' allele of IFN- $\gamma$ rs2069705 was remarkably associated with higher ODI score in a study, as the patients with 'AA' and 'GA' genotypes had significantly higher ODI scores. In addition, the 'AG' and 'GG' genotypes of IFN- $\gamma$ rs 2069718 were associated with higher ODI scores in this Norwegian population [3].

The IL-12 mainly functions together with other cytokines such as IFN- $\gamma$, and the levels of these cytokines were different in fragments of herniated discs and degenerative disc tissue. Accordingly, both IL-12 and IFN$\gamma$, as well as other cytokines (IL-4, IL-6) indicated higher levels in the fragments of herniated discs [4]. On the other hands, the expression levels of these cytokines were not remarkably different between nucleous pulposus and anulus fibrosus of healthy discs obtained from autopsies [4].

Although the IL-2 plays an important role in inflammatory processes, its expression level was not significantly different between acute or chronic low back pain, or even the asymptomatic subjects [11]. Moreover, the IL-2 level was not associated with VAS scores either in acute or chronic low back pain [11]. In a study measuring the levels of different cytokines in low back pain, IL-

Table 3 Association between cytokine genotypes and 2 months or 6 months postop OSW changes in IVDD patients

\begin{tabular}{|c|c|c|c|c|c|c|}
\hline \multirow[t]{2}{*}{ Cytokine } & \multirow[t]{2}{*}{ Position } & \multirow[t]{2}{*}{ Genotype } & \multicolumn{2}{|c|}{2 months postop } & \multicolumn{2}{|c|}{6 months postop } \\
\hline & & & $\mathrm{MD} \pm \mathrm{SD}(\mathrm{MD})$ & $\boldsymbol{P}$-value & $\mathrm{MD} \pm \mathrm{SD}(\mathrm{MD})$ & $\boldsymbol{P}$-value \\
\hline \multirow[t]{3}{*}{$\overline{I L}-12$} & \multirow[t]{3}{*}{-1188} & $\mathrm{AA}$ & $-18.75 \pm 5.69$ & \multirow[t]{3}{*}{0.19} & $-24.54 \pm 5.60$ & \multirow[t]{3}{*}{0.07} \\
\hline & & CA & $-21.36 \pm 6.01$ & & $-27.59 \pm 3.69$ & \\
\hline & & $\mathrm{CC}$ & $-21.50 \pm 5.08$ & & $-26.50 \pm 5.16$ & \\
\hline \multirow[t]{3}{*}{ IFN- $\gamma$} & \multirow[t]{3}{*}{+874} & AA & $-20.08 \pm 5.44$ & \multirow[t]{3}{*}{0.99} & $-25.82 \pm 4.54$ & \multirow[t]{3}{*}{0.98} \\
\hline & & AT & $-20.11 \pm 5.92$ & & $-25.92 \pm 5.18$ & \\
\hline & & $\pi$ & $-20.35 \pm 6.12$ & & $-25.57 \pm 6.33$ & \\
\hline \multirow[t]{3}{*}{ IL-2 } & \multirow[t]{3}{*}{-330} & GG & $-27.50 \pm 0.70$ & \multirow[t]{3}{*}{0.12} & $-28.00 \pm 2.82$ & \multirow[t]{3}{*}{0.82} \\
\hline & & TG & $-19.54 \pm 5.90$ & & $-25.80 \pm 5.27$ & \\
\hline & & $\pi$ & $-21.37 \pm 4.03$ & & $-25.50 \pm 4.75$ & \\
\hline \multirow[t]{3}{*}{$\mathrm{IL}-2$} & \multirow[t]{3}{*}{+166} & GG & $-20.66 \pm 5.38$ & \multirow[t]{3}{*}{0.33} & $-26.21 \pm 4.27$ & \multirow[t]{3}{*}{0.27} \\
\hline & & GT & $-19.12 \pm 6.14$ & & $-25.19 \pm 5.85$ & \\
\hline & & TT & -26.00 & & -33.00 & \\
\hline
\end{tabular}


Table 4 Association between cytokine genotypes and 2 months or 6 months postop VAS changes in IVDD patients

\begin{tabular}{|c|c|c|c|c|c|c|}
\hline \multirow[t]{2}{*}{ Cytokine } & \multirow[t]{2}{*}{ Position } & \multirow[t]{2}{*}{ Genotype } & \multicolumn{2}{|c|}{2 months postop } & \multicolumn{2}{|c|}{6 months postop } \\
\hline & & & $\mathrm{MD} \pm \mathrm{SD}(\mathrm{MD})$ & $\boldsymbol{P}$-value & $\mathrm{MD} \pm \mathrm{SD}(\mathrm{MD})$ & $\boldsymbol{P}$-value \\
\hline \multirow[t]{3}{*}{ IL-12 } & \multirow[t]{3}{*}{-1188} & AA & $-4.37 \pm 1.42$ & \multirow[t]{3}{*}{0.52} & $-5.62 \pm 1.29$ & \multirow[t]{3}{*}{0.49} \\
\hline & & CA & $-4.77 \pm 1.10$ & & $-5.90 \pm 1.06$ & \\
\hline & & CC & $-4.50 \pm 0.83$ & & $-6.16 \pm 1.47$ & \\
\hline \multirow[t]{3}{*}{ IFN- $\gamma$} & \multirow[t]{3}{*}{+874} & AA & $-4.65 \pm 1.19$ & \multirow[t]{3}{*}{0.49} & $-5.86 \pm 1.09$ & \multirow[t]{3}{*}{0.92} \\
\hline & & AT & $-4.37 \pm 1.49$ & & $-5.74 \pm 1.48$ & \\
\hline & & $\pi$ & $-4.85 \pm 0.94$ & & $-5.85 \pm 0.94$ & \\
\hline \multirow[t]{3}{*}{ IL-2 } & \multirow[t]{3}{*}{-330} & GG & $-6.00 \pm 0$ & \multirow[t]{3}{*}{0.22} & $-6.00 \pm 0$ & \multirow[t]{3}{*}{0.88} \\
\hline & & $\mathrm{TG}$ & $-4.56 \pm 1.31$ & & $-5.83 \pm 1.21$ & \\
\hline & & TT & $-4.25 \pm 0.88$ & & $-5.62 \pm 1.50$ & \\
\hline \multirow[t]{3}{*}{ IL-2 } & \multirow[t]{3}{*}{+166} & GG & $-4.57 \pm 1.27$ & \multirow[t]{3}{*}{0.90} & $-5.84 \pm 1.12$ & \multirow[t]{3}{*}{0.18} \\
\hline & & GT & $-4.58 \pm 1.31$ & & $-5.70 \pm 1.29$ & \\
\hline & & $\pi$ & -4.00 & & -8.00 & \\
\hline
\end{tabular}

2 levels in the sera of patients with low back pain were remarkably lower than controls, similar to other factors including IL-6, IL-4, and MMP-1. On the other hands, the serum levels of IL-12 and IFN- $\gamma$ were not significantly different between patients and healthy controls [12]. However, another study indicated higher levels of IL-2 and IL-12 in degenerated disc tissue compared to controls [13]. Another study confirmed this finding, as both the mRNA level and protein level of IL-2 were higher in prolapsed NP cells than controls [14].

In an animal model of disc herniation in rats, presence of NP and IFN- $\gamma$ in the dorsal nerve root of animals resulted in remarkable higher activity of nociceptive neurons [3]. The intervertebral disc degeneration would affect different components of spinal cord, in addition to disc itself. The inflammatory process and destructive damages would also affect the spinal components such as epidural space. It could be explained as the inflammation in this component would have compressive effect on nerve roots and cause more severe clinical manifestations. Accordingly, in a canine model of disc degeneration, the cytokine levels were assessed in different stages of disc extrusion. Importantly, the expression level of IL-2 was significantly decreased in disc extrusion, especially in the subacute stage [15]. However, another animal model in rabbits showed contradictory results, as the IL-2 level was significantly increased not only in degenerated disc tissue, but also in the sera of animals. Moreover, in that model, the effect of plasma vaporization ablation was evaluated for treatment of IVDD. The expression levels of IL-12, as well as some other cytokines such as IL- 4 and TNF- $\alpha$, were decreased after applying this method, which could indicate its effectiveness in treating IVDD [16]. The mRNA expression of IL-2 was also remarkably higher in another model of disc herniation in rats [17]. In an animal model of disc herniation in rats, dorsal root ganglions were exposed to $\mathrm{NP}$, and epidural lavage indicated higher expression of IFN- $\gamma$, as well as other cytokines such as IL-4, IL-6, and TNF- $\alpha[18]$.

Taking limitations of current study to account, small sample size could be considered as one of them, and

Table 5 Association between cytokine allele frequencies and 2 months or 6 months postop OSW changes in IVDD patients

\begin{tabular}{|c|c|c|c|c|c|c|}
\hline \multirow[t]{2}{*}{ Cytokine } & \multirow[t]{2}{*}{ Position } & \multirow[t]{2}{*}{ Allele } & \multicolumn{2}{|c|}{2 months postop } & \multicolumn{2}{|c|}{6 months postop } \\
\hline & & & $\mathrm{MD} \pm \mathrm{SD}(\mathrm{MD})$ & $\boldsymbol{P}$-Value & $\mathrm{MD} \pm \mathrm{SD}(\mathrm{MD})$ & $\boldsymbol{P}$-Value \\
\hline \multirow[t]{2}{*}{ IL-12 } & \multirow[t]{2}{*}{-1188} & A & $-19.35 \pm 5.81$ & \multirow[t]{2}{*}{0.07} & $-25.23 \pm 5.33$ & \multirow[t]{2}{*}{0.05} \\
\hline & & C & $-21.41 \pm 5.55$ & & $-27.20 \pm 4.13$ & \\
\hline \multirow[t]{2}{*}{ IFN- $\gamma$} & \multirow[t]{2}{*}{+874} & A & $-20.09 \pm 5.54$ & \multirow[t]{2}{*}{0.89} & $-25.86 \pm 4.72$ & \multirow[t]{2}{*}{0.89} \\
\hline & & $\mathrm{T}$ & $-20.23 \pm 5.91$ & & $-25.74 \pm 5.68$ & \\
\hline \multirow[t]{2}{*}{ IL-2 } & \multirow[t]{2}{*}{-330} & G & $-20.08 \pm 6.04$ & \multirow[t]{2}{*}{0.90} & $-25.94 \pm 5.14$ & \multirow[t]{2}{*}{0.81} \\
\hline & & $\mathrm{T}$ & $-19.95 \pm 5.54$ & & $-25.73 \pm 5.09$ & \\
\hline \multirow[t]{2}{*}{ IL-2 } & \multirow[t]{2}{*}{+166} & G & $-20.17 \pm 5.62$ & \multirow[t]{2}{*}{0.58} & $-25.88 \pm 4.80$ & \multirow[t]{2}{*}{0.83} \\
\hline & & $\mathrm{T}$ & $-19.54 \pm 6.17$ & & $-25.66 \pm 5.97$ & \\
\hline
\end{tabular}


Table 6 Association between cytokine allele frequencies and 2 months or 6 months postop VAS changes in IVDD patients

\begin{tabular}{|c|c|c|c|c|c|c|}
\hline \multirow[t]{2}{*}{ Cytokine } & \multirow[t]{2}{*}{ Position } & \multirow[t]{2}{*}{ Allele } & \multicolumn{2}{|c|}{2 months postop } & \multicolumn{2}{|c|}{6 months postop } \\
\hline & & & $\mathrm{MD} \pm \mathrm{SD}(\mathrm{MD})$ & $\boldsymbol{P}$-Value & $\mathrm{MD} \pm \mathrm{SD}(\mathrm{MD})$ & $\boldsymbol{P}$-Value \\
\hline \multirow[t]{2}{*}{ IL-12 } & -1188 & A & $-4.46 \pm 1.35$ & 0.41 & $-5.68 \pm 1.24$ & 0.20 \\
\hline & & C & $-4.67 \pm 1.00$ & & $-6.00 \pm 1.18$ & \\
\hline \multirow[t]{2}{*}{ IFN- $\gamma$} & +874 & A & $-4.54 \pm 1.30$ & 0.75 & $-5.82 \pm 1.23$ & 0.92 \\
\hline & & $\mathrm{T}$ & $-4.61 \pm 1.25$ & & $-5.80 \pm 1.22$ & \\
\hline \multirow[t]{2}{*}{ IL-2 } & -330 & G & $-4.66 \pm 1.32$ & 0.45 & $-5.84 \pm 1.17$ & 0.78 \\
\hline & & $\mathrm{T}$ & $-4.49 \pm 1.22$ & & $-5.78 \pm 1.26$ & \\
\hline \multirow[t]{2}{*}{ IL-2 } & +166 & G & $-4.57 \pm 1.27$ & 0.90 & $-5.80 \pm 1.16$ & 0.85 \\
\hline & & T & $-4.54 \pm 1.27$ & & $-5.84 \pm 1.37$ & \\
\hline
\end{tabular}

therefore, a larger sample size could improve random error or increase the study power. Meanwhile, the genetic factors may have co-effect on each other, and therefore a wider panel measuring the role of different cytokines and other genetic factors could be helpful if better understanding of the role of each factor. Moreover, it shall be considered that assessment of gene SNPs together with expression levels or protein levels would more confidently demonstrate the association between genetic factors and disease. As it was not applicable to measure the IL-2 and other cytokine levels in this study, it is recommended to be considered in the future studies. It should be also considered that the status of some SNPs could not be interpreted though electrophoresis gels in some samples, and therefore, those patients were not included in the analysis for that particular SNP.

\section{Conclusion}

Cytokines variants including IL-2 $-330 \mathrm{~T} / \mathrm{G}$ could be considered as a predisposing factor for IVDD, as the 'TG' genotype was twice more common in Iranian adults with IVDD. As the importance of IVDD in daily lives of working population, understanding genetic predispositions could be invaluable to detect high risk individuals, and therefore, consider some preventive conditions for them, such as avoiding them to choose jobs which involve high load on lumbar discs. In addition, detecting the genetic factors which influence the response to treatment, could be helpful in approaching the patients. In other words, patients with a specific gene variant (exe. IL-12 -1188A/C) might benefit more from surgery, as their post-operative ODI were lower than pre-operative measurements.

\section{Abbreviations}

IFN-ү: Interferon gamma; IL-12: Interleukin 12; IL-2: Interleukin 2; IVDD: Intervertebral Disc Degeneration; NP: Nucleous Pulposus; OD: Optical Density; ODI: Owestry Disability Index; OR: Odds Ratio; PCR: Polymerase Chain Reactions; PCR-SSP: Sequence Specific Prime PCR; SNP: Single Nucleotide Polymorphisms; TNF-a: Tumor Necrosis Factor alpha; VAS: Visual Analogue Scale

\section{Acknowledgements}

The authors would like to kindly thank the patients and lab staff for their kind cooperation in executive management of this manuscript.

\section{Authors' contributions}

All authors agree that this is the authors' own work and all the study objectives have been appropriately investigated, and reported. They have all read and approved the final version of manuscript. The authors' contribution in the study was as follow: SH prepared the proposal, performed laboratory tests, interpreted the results, drafted the manuscript, and confirmed the final manuscript. SA contributed in designing the study, provided samples, revised the manuscript, and confirmed the final manuscript. MS performed the laboratory tests, interpreted the results, and confirmed the final manuscript. MHM provided samples, cooperated in collecting the clinical data, substantively revised the clinical part of the manuscript, and confirmed the final manuscript. EF provided samples, cooperated in collecting the clinical data, substantively revised the clinical part of the manuscript, and confirmed the final manuscript. ARK contributed in study design, provided samples, supervised the project as the clinical expert, substantively revised the manuscript, and confirmed the final manuscript. NR designed the study, critically revised the manuscript, supervised the whole study as the expert, and confirmed the final manuscript.

\section{Funding}

Research reported in this publication was not financially funded by any organization. However, the project was supported by Tehran University of Medical Sciences, as all the lab tests were performed in the Molecular Immunology Research Center, Tehran University of Medical Sciences. This cooperation included no financial support or budget from that research center.

\section{Availability of data and materials}

The data that support the findings of this study are available from the corresponding author (Nima Rezaei) but restrictions apply to the availability of these data, which were used under license for the current study, and so are not publicly available. Data are however available from the authors upon reasonable request and with permission of the corresponding author (Nima Rezaei). Meanwhile, it shall be noted that no dataset was generated or used for this project.

\section{Ethics approval and consent to participate}

All procedures performed in studies involving human participants were in accordance with the ethical standards of the institutional and/or national research committee and with the 1964 Helsinki declaration and its later amendments or comparable ethical standards. All the study participants were adults over 18 years, and written informed consent to participate was obtained from all of study participants prior to recruitment and sampling. The study was approved by Ethics Committee of Tehran University of Medical Sciences.

Consent for publication Not applicable. 
The current manuscript does not include any details, images, or videos relating to an individual person.

\section{Competing interests}

The authors declare that they have no competing interests.

\section{Author details}

${ }^{1}$ Molecular Immunology Research Center, Tehran University of Medical Sciences, Tehran, Iran. ${ }^{2}$ Research Center for Immunodeficiencies, Children's Medical Center, Tehran University of Medical Sciences, Dr Qarib St, Keshavarz Blvd, Tehran 14194, Iran. ${ }^{3}$ Network of Immunity in Infection, Malignancy and Autoimmunity (NIIMA), Universal Scientific Education and Research Network (USERN), Tehran, Iran. ${ }^{4}$ Division of neurosurgery, Department of surgery, Rajayi Hospital, Qazvin University of Medical Sciences, Qazvin, Iran. ${ }^{5}$ Department of Neurosurgery, Shariati Hospital, Tehran University of Medical Sciences, Tehran, Iran. 'Department of Immunology, School of Medicine, Tehran University of Medical Sciences, Tehran, Iran.

Received: 11 April 2020 Accepted: 29 June 2020

Published online: 03 July 2020

\section{References}

1. Hanaei S, Abdollahzade S, Khoshnevisan A, Kepler CK, Rezaei N. Genetic aspects of intervertebral disc degeneration. Rev Neurosci. 2015;26(5):581606.

2. Online Mendelian Inheritance in Man, $\mathrm{OMIM}^{\oplus}$. McKusick-Nathans Institute of Genetic Medicine, Johns Hopkins University (Baltimore), 2020. World Wide Web URL: https://omim.org/.

3. Moen G-H, Moen A, Schistad El, Gjerstad J. Local up-regulation of interferon- $\gamma$ (IFN- $\gamma$ ) following disc herniation is involved in the inflammatory response underlying acute lumbar radicular pain. Cytokine. 2017;97:181-6.

4. Shamii MF, Setton LA, Jarvis W, So S, Chen J, Jing L, Bullock R, Isaacs RE, Brown C, Richardson WJ. Proinflammatory cytokine expression profile in degenerated and herniated human intervertebral disc tissues. Arthritis Rheum. 2010;62(7):1974-82.

5. Kamieniak P, Bielewicz J, Grochowski C, Litak J, Bojarska-Junak A, Daniluk B, Trojanowski T. The elevated serum level of IFN- $\gamma$ in patients with failed Back surgery syndrome remains unchanged after spinal cord stimulation. Dis Markers. 2019;2019:2606808.

6. Abdollahzade S, Hanaei S, Sadr M, Mirbolouk MH, Fattahi E, Rezaei N, Khoshnevisan A. Significant association of TNF-a, but not other proinflammatory cytokines, single nucleotide polymorphisms with intervertebral disc degeneration in Iranian population. Clin Neurol Neurosurg. 2018;173:77-83

7. Hanaei S, Abdollahzade S, Sadr M, Mirbolouk MH, Fattahi E, Khoshnevisan A Rezaei N. The role of interleukin 4 and IL-4RA in intervertebral disc degeneration: investigation of single nucleotide polymorphisms in genes and a systematic review \& meta-analysis of IL-4 expression level. $\mathrm{Br} J$ Neurosurg. 2020;34(1):66-71.

8. Hanaei S, Abdollahzade S, Sadr M, Mirbolouk MH, Khoshnevisan A, Rezaei N. Association of IL10 and TGFB single nucleotide polymorphisms with intervertebral disc degeneration in Iranian population: a case control study. BMC Med Genet. 2018;19(1):59.

9. Fairbank JC, Pynsent PB. The Oswestry disability index. Spine. 2000;25(22): 2940-53.

10. Loparev V, Cartas M, Monken C, Velpandi A, Srinivasan A. An efficient and simple method of DNA extraction from whole blood and cell lines to identify infectious agents. J Virol Methods. 1991:34(1):105-12.

11. Teodorczyk-Injeyan JA, Triano JJ, Injeyan HS. Nonspecific low Back pain: inflammatory profiles of patients with acute and chronic pain. Clin J Pain. 2019;35(10):818

12. Weber KT, Alipui DO, Sison CP, Bloom O, Quraishi S, Overby MC, Levine M, Chahine NO. Serum levels of the proinflammatory cytokine interleukin-6 vary based on diagnoses in individuals with lumbar intervertebral disc diseases. Arthritis Res Ther. 2016;18(1):3.

13. Akyol S, Eraslan BS, Etyemez H, Tanriverdi T, Hanci M. Catabolic cytokine expressions in patients with degenerative disc disease. Turkish Neurosurg. 2010;20(4):492-9.

14. Wang Z, Wang G, Zhu X, Geng D, Yang H. Interleukin-2 is upregulated in patients with a prolapsed lumbar intervertebral disc and modulates cell proliferation, apoptosis and extracellular matrix metabolism of human nucleus pulposus cells. Exp Ther Med. 2015:10(6):2437-43.

15. Karli $P$, Martlé $V$, Bossens $K$, Summerfield A, Doherr MG, Turner $P$, Vandevelde $M$, Forterre F, Henke D. Dominance of chemokine ligand 2 and matrix metalloproteinase-2 and-9 and suppression of pro-inflammatory cytokines in the epidural compartment after intervertebral disc extrusion in a canine model. Spine J. 2014;14(12):2976-84.

16. Peng $T, X u X$, Shan $G$, Wang $H$. Effects of plasma vaporization ablation on expression of inflammatory factors in rabbit model of intervertebral disc degeneration; 2018

17. $\mathrm{Xu} Z$ Z, Zhou $X$, Chen $\mathrm{G}$. Expression and mechanism of interleukin 1 (IL-1) interleukin 2 (IL-2), interleukin 8 (IL-8), BMP, fibroblast growth factor 1 (FGF1), and insulin-like growth factor (IGF-1) in lumbar disc herniation. Med Sci Monit. 2019;25:984-90.

18. Cuellar JM, Borges PM, Cuéllar VG, Yoo A, Scuderi GJ, Yeomans DC. Cytokine expression in the epidural space: a model of non-compressive disc herniation-induced inflammation. Spine. 2013;38(1):17-23.

\section{Publisher's Note}

Springer Nature remains neutral with regard to jurisdictional claims in published maps and institutional affiliations.
Ready to submit your research? Choose BMC and benefit from:

- fast, convenient online submission

- thorough peer review by experienced researchers in your field

- rapid publication on acceptance

- support for research data, including large and complex data types

- gold Open Access which fosters wider collaboration and increased citations

- maximum visibility for your research: over $100 \mathrm{M}$ website views per year

At $\mathrm{BMC}$, research is always in progress.

Learn more biomedcentral.com/submissions 